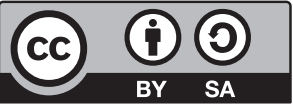

\title{
Wybrane zagadnienia związane ze stosowaniem instytucji usiłowania we współczesnym orzecznictwie sądów polskich
}

\begin{abstract}
The institution of attempt is used relatively frequently in the practice of justice system.

Importantly, it always separates the punishable stage of attempt from punishable preparatory activities, and therefore constitutes the limit of criminalization. Despite its practical importance, using of the indicated legal structure, raises a number of doubts that are related to the proper interpretation of the normative concepts comprising it. A consequence is moving the limit of punishability of the crime by adjudicating authorities. It can raise some objections - from fundamental principle of criminal law in the form of nullum crimen sine lege point of view. The article discusses the problems of that appear in jurisdiction in connection with the application of the attempt institution; these problems raise interest among doctrine. The author confronts irreconcilable judgments. The Author searches interpretative solutions that seem the most appropriate from theoretical and dogmatic structure of the successful attempt and inept attempt point of view.
\end{abstract}

Keywords: successful attempt, inept attempt, aiming directly to commit a crime, an object that is suitable for committing a criminal act on it.

\section{Wstęp}

Usiłowanie pomimo swojej wieloletniej kodeksowej tradycji ${ }^{1}$ należy bez wątpienia do jednej z najbardziej kontrowersyjnych instytucji prawa

${ }^{1}$ Już w tym miejscu należy bowiem zauważyć, że zarówno Kodeks karny z 1932 r., jak również jego następca z 1969 r. przewidywały rozszerzenie karalności na formę stadialną 
karnego. W dyskusji nad jej kształtem wciąż aktualne pozostają wypowiedziane w 1868 r. słowa S. Budzińskiego, który podkreślał, iż „nie ma materyi w prawie karném, bardziéj otwierającéj pole do różnorodnych poglądów, jak usiłowanie"" . Przywołane słowa bardzo dobitnie obrazują nie tylko trwające od wielu lat w doktrynie spory koncentrujące się wokół podstawowych pojęć związanych z figurą usiłowania, ale również wyraźne rozbieżności w orzecznictwie, na gruncie którego określony stan faktyczny nierzadko kwalifikowany jest na podstawie trzech odrębnych przepisów dotyczących form stadialnych przestępstwa ${ }^{3}$. Należy przy tym zauważyć, że debata nad problematyką usiłowania, w tym również usiłowania nieudolnego, nie ma charakteru wyłącznie akademickiego. Omawiana instytucja, zajmując $\mathrm{w}$ tzw. pochodzie przestępstwa miejsce między przygotowaniem a dokonaniem, stanowi w większości przypadków granicę kryminalizacji, zawsze zaś jest elementem decydującym o rozmiarach odpowiedzialności karnej ${ }^{4}$. Ponadto nie wolno przejść do porządku nad tym, że usiłowanie wiąże się z ochroną dobra prawnego niekiedy na bardzo dalekim przedpolu jego naruszenia, co prowokuje oczywiste pytanie o dopuszczalną ingerencję prawa karnego w sferę praw i wolności jednostki ${ }^{5}$. Także z per-

usiłowania przestępstwa, przy czym kształt normatywny omawianej instytucji nie różnił się w sposób zasadniczy od współczesnego jej uregulowania. Wprowadzone na gruncie Kodeksu karnego z 1997 r. zmiany miały raczej charakter porządkowo-stylistyczny aniżeli merytoryczny.

2 S. BuDziński: Wykład porównawczy prawa karnego. Warszawa 1868, s. 163.

3 Taka sytuacja miała miejsce choćby przed Sądem Apelacyjnym w Katowicach, który rozpoznawał sprawę oskarżonych m.in. o usiłowanie rozboju polegającego na tym, iż sprawcy oczekiwali na ofiarę w piwnicy, jednak po pojawieniu się w planowanym miejscu zamachu osoby trzeciej napad został odwołany. Powyższy stan faktyczny przez sąd okręgowy został zakwalifikowany jako usiłowanie nieudolne, następnie - po uwzględnieniu apelacji prokuratora - sąd apelacyjny uchylił wyrok i sprawę przekazał do ponownego rozpoznania, wskazując, iż zachowanie sprawców stanowiło realne zagrożenie dla dóbr prawnych, natomiast rozpoznający ostatecznie sprawę Sąd Apelacyjny w Katowicach przyjął, że sprawa dotyczy co najwyżej niekaralnego etapu przygotowania. Wyr. SA w Katowicach z dnia 25 kwietnia 2019 r., II AKa 415/17. LEX nr 2728176.

4 J. GIEZEK: Formy stadialne popetnienia przestępstwa w polskim prawie karnym. „Annales Universitatis Mariae Curie-Skłodowska" 2013, vol. 60, nr 2, s. 46.

${ }^{5}$ Jak wskazuje Z. Jędrzejewski, spór dotyczący usiłowania nieudolnego stanowi jednocześnie spór o sens i zakres represji karnej. Z. JĘDRZEJEWsKI: Bezprawie usiłowania nieudolnego. Warszawa 2000, s. 10 . Z perspektywy dopuszczalnej ingerencji prawa karnego może zastanawiać karalność tych przypadków, w których występuje bezwzględny brak przedmiotu czynności wykonawczej. Jako przykład może posłużyć choćby wyr. SA w Katowicach z dnia 31 marca 2017 r., w którym sąd ten stwierdził, iż „Podjęte przez sprawcę działanie zmierzające do umyślnego pozbawienia życia człowieka przy braku świadomości, że jest on martwy, stanowi usiłowanie nieudolne (art. 13 § 2 k.k.) zbrodni zabójstwa" - wyr. SA w Katowicach z dnia 31 marca 2017 r., II AKa 48/17. LEX nr 2310584. Powstaje bowiem pytanie, w jaki sposób uzasadniać karalność tego rodza- 
spektywy gwarancyjnej funkcji prawa karnego jako wyjątkowo istotne jawi się zatem wytyczenie swoistej linii demarkacyjnej zarówno między usiłowaniem udolnym a nieudolnym, jak również między usiłowaniem nieudolnym a tymi zachowaniami, które z punktu widzenia norm prawnokarnych powinny pozostać całkowicie irrelewantne.

Mając zatem na uwadze doniosłą funkcję usiłowania zarówno dla teoretyków i praktyków prawa karnego, jak również obywateli, niniejszy artykuł ma na celu wskazanie najistotniejszych problemów związanych ze stosowaniem tejże instytucji we współczesnym orzecznictwie sądów polskich. Jednocześnie stanowi on próbę sformułowania takich rozwiązań interpretacyjnych, które wydają się najbardziej właściwe z punktu widzenia teoretycznej oraz dogmatycznej konstrukcji usiłowania.

\section{Relacja między usiłowaniem udolnym a nieudolnym}

W charakterze wstępu do dalszych rozważań należy wskazać, że zgodnie z dyspozycją art. $13 \S 1$ k.k. „odpowiada za usiłowanie, kto w zamiarze popełnienia czynu zabronionego swoim zachowaniem bezpośrednio zmierza do jego dokonania, które jednak nie następuje”. Natomiast jego $\S 2$ stanowi, iż „usiłowanie zachodzi także wtedy, gdy sprawca nie uświadamia sobie, że dokonanie jest niemożliwe ze względu na brak przedmiotu nadającego się do popełnienia na nim czynu zabronionego lub ze względu na użycie środka nie nadającego się do popełnienia czynu zabronionego".

W kontekście przywołanego przepisu trzeba odnotować, że w piśmiennictwie dyskusyjna pozostaje wzajemna relacja art. $13 \S 1$ k.k. statuującego znamiona usiłowania udolnego oraz art. 13 § 2 k.k. określającego przesłanki usiłowania nieudolnego. Główną oś sporu stanowi pytanie, czy usiłowanie nieudolne można uznać za odmianę usiłowania udolnego ${ }^{6}$, czy też należy je traktować jako samodzielną formę stadialną przestępstwa, co implikuje wniosek, że art. $13 \S 2$ k.k. pozostaje niezależny treściowo od art. $13 \S 1$ k.k. ${ }^{7}$. Należy wskazać, że utrzymujące się w tym zakresie spory

ju zachowań, skoro niebezpieczna wola sprawcy - wobec nieistnienia obiektu, na który skierował on swój zamach - nie odznaczała się żadną, nawet potencjalną zdolnością realizacyjną.

${ }^{6}$ Tak np. A. Zoll, który podnosi, że do usiłowania nieudolnego należy odnosić wszystkie znamiona wskazane w art. $13 \S 1$ k.k. Tym samym art. $13 \S 1$ k.k. traktowany jest jako lex generalis, zaś art. $13 \S 2$ k.k. jako lex specialis. Zob. A. Zoll: Formy popetnienia przestępstwa. W: Kodeks Karny. Część Ogólna. Tom I. Komentarz do art. 1-52. Red. W. WróBeL, A. Zoll. Warszawa 2016. s. 291.

7 J. MAJEWSKI: O różnicy i granicy między usiłowaniem udolnym a usiłowaniem nieudolnym. W: Formy stadialne i postacie zjawiskowe popetnienia przestępstwa. Red. IDEM. Toruń 2007, s. 27 i nast. 
teoretyczno-doktrynalne znajdują odzwierciedlenie w praktyce stosowania prawa. Przykładem jest wyrok Sądu Okręgowego w Poznaniu z dnia 31 grudnia 2014 r., w którym sąd ten przyjął, iż „usiłowanie nieudolne jest odmianą usiłowania i w związku z tym musi wyczerpywać wszystkie znamiona usiłowania z modyfikacją wynikającą jedynie $\mathrm{z}$ istoty nieudolnego charakteru zachowania sprawcy"s. Na odmiennym stanowisku stanął z kolei Sąd Rejonowy dla Warszawy-Mokotowa w Warszawie, który w wyroku z dnia 11 grudnia 2015 r. skonstatował: „[...] Wskazać należy, iż usiłowanie nieudolne $\mathrm{z}$ art. $13 \S 2 \mathrm{k} . \mathrm{k}$. nie stanowi lex specialis $\mathrm{w}$ stosunku do usiłowania $\mathrm{z}$ art. $13 \S 1 \mathrm{k} . \mathrm{k} .$, a tym samym nie jest szczególnym rodzajem usiłowania udolnego [...]. Tym samym usiłowanie nieudolne należy traktować jako dodatkowy typ usiłowania, uregulowany obok usiłowania udolnego"9.

Trzeba również zaznaczyć, że problematyka stosunku usiłowania udolnego do nieudolnego nie ma charakteru wyłącznie teoretycznego. Po pierwsze, wydaje się, iż ustalenie zakresu zależności pomiędzy tymi dwiema figurami prawnymi będzie rzutować na sposób interpretacji znamion składających się na art. 13 § 2 k.k., w tym zwłaszcza elementu bezpośredniego zmierzania do dokonania czynu zabronionego ${ }^{10}$. W tym kontekście nasuwa się pytanie, czy sprawca, którego zachowanie - z uwagi na brak możliwości dokonania - nie stanowi żadnego zagrożenia dla dóbr prawnych, może bezpośrednio, a zatem wprost, bez ogniw pośrednich ${ }^{11}$ zmierzać do dokonania czynu zabronionego i czy taka wykładnia po-

8 Wyr. SO w Poznaniu z dnia 31 grudnia 2014 r., III K 250/14. Źródło: http://orzeczenia.ms.gov.pl/details/\$N/153510000001506_III_K_000250_2014_Uz_2015-01-22_001 [dostęp: 22.03.2021]. Na tożsamym stanowisku stanął SA w Białymstoku w wyr. z dnia 21 stycznia 2014 r., II AKa 259/13. LEX nr 1496372.

9 Wyr. SR dla Warszawy-Mokotowa w Warszawie z dnia 11 grudnia 2015 r., XIV K 220/15. Źródło: http://orzeczenia.ms.gov.pl/details/\$N/154505200007006_ XIV_K_000220_2015_Uz_2015-12-11_001 [dostęp: 22.03.2021].

${ }_{10}$ Trzeba wskazać, że zgodnie z przeważającym stanowiskiem doktryny właściwego ujęcia bezpośredniości, o której mowa art. 13 \$ 1 k.k., należy poszukiwać wyłącznie w ramach koncepcji przedmiotowych, na gruncie których kluczowe znaczenie mają elementy obiektywne, nie zaś subiektywne przekonanie sprawcy, że swoim zachowaniem zmierza do dokonania. Tak np. O. Sitarz: Czynny żal zwiqzany z usiłowaniem $w$ polskim prawie karnym. Analiza dogmatyczna i kryminalnopolityczna. Katowice 2015, s. 141. Za koncepcją obiektywną opowiedziała się również G. RejMAN: Usiłowanie przestępstwa $w$ prawie polskim. Warszawa 1965, s. 30 i nast.

${ }^{11}$ Należy zauważyć, że słownik języka polskiego pojęcie „bezpośredni” definiuje jako: 1. dotyczący czegoś wprost; 2. znajdujący się bardzo blisko. Natomiast słowo „bezpośrednio" według definicji słownikowej oznacza: 1 . bez jakiegokolwiek pośrednictwa; 2 . tuż za czymś lub tuż przed czymś; 3. w chwili następującej po czymś lub poprzedzającej coś Stownik języka polskiego PWN. Red. E. Sobol, L. DrabiK. Warszawa 2007, s. 49-50. 
zostaje spójna z subiektywistycznym ujęciem usiłowania nieudolnego ${ }^{12}$. Po drugie, jak słusznie skonstatował J. Majewski, traktowanie art. 13 $\S 2$ k.k. jako lex specialis w stosunku do art. 13 § 1 k.k. winno skutkować przyjęciem, że hipoteza normy odnoszącej się do usiłowania udolnego obejmuje wszystkie te przypadki, których nie można zakwalifikować jako usiłowanie nieudolne. Powyższe byłoby zaś nie do pogodzenia z regulacją ustawową, która nieskuteczność dokonania z uwagi na błąd co do podmiotu czy też okoliczności modalnych czynu pozostawia przecież poza sferą karalności, a tym samym zainteresowania prawa karnego ${ }^{13}$. Należy również zauważyć, iż akceptacja tezy, że usiłowanie nieudolne stanowi wyłącznie odmianę usiłowania udolnego, niesie ze sobą określone implikacje praktyczne także na gruncie prawa wykroczeń. Aby nie narazić się na zarzut braku konsekwencji, trzeba bowiem stanąć na stanowisku, że pomimo braku w tym zakresie wyraźnej regulacji ustawowej - w ramach art. 10 k.w. ${ }^{14}$ karalne są wszystkie przypadki usiłowania nieudolnego wykroczenia. Dopiero przyjęcie, iż przepis art. 13 \$ 2 k.k. rozszerza granicę karalności usiłowania, stanowiąc tym samym specyficzną i odrębną konstrukcję prawną, uzasadnia wniosek, że w prawie wykroczeń instytucja usiłowania nieudolnego nie obowiązuje ${ }^{15}$.

Mając na uwadze powyższe, trafne wydaje się postrzeganie usiłowania nieudolnego jako samodzielnej, niezależnej od usiłowania udolnego formy stadialnej przestępstwa. Należy podkreślić, że pomiędzy usiłowaniem udolnym a nieudolnym zachodzą zasadnicze różnice, które niejako wymuszają odrębne definiowanie znamion każdego z nich. Usiłowanie udolne oceniane $\mathrm{z}$ perspektywy ex ante obiektywnie może doprowadzić do

12 Nie ulega wątpliwości, że niezależnie od prób poszukiwania elementu obiektywnego przy uzasadnieniu bezprawności usiłowania nieudolnego $\mathrm{w}$ procesie przypisywania odpowiedzialności karnej za tę formę stadialną przestępstwa dominującą rolę odgrywają komponenty subiektywne w postaci zamiaru sprawcy oraz jego motywacji. Z uwagi na brak zagrożenia dla dóbr prawnych nie da się bowiem ustalić bezprawności, a następnie karalności usiłowania nieudolnego w oderwaniu od elementu wolitywnego.

13 Więcej na ten temat zob. J. MajEwski: O różnicy i granicy między usiłowaniem udolnym a usitowaniem nieudolnym. W: Formy stadialne..., s. 28 i nast.

${ }^{14}$ Treść przywołanego przepisu jest następująca: „\$1. Odpowiada za usiłowanie, kto $w$ zamiarze popetnienia czynu zabronionego swoim zachowaniem bezpośrednio zmierza do jego dokonania, które jednak nie następuje. § 2. Odpowiedzialność za usiłowanie zachodzi, gdy ustawa tak stanowi. \$3. Karę za usitowanie wymierza się $w$ granicach zagrożenia przewidzianego dla danego wykroczenia. \$4. Nie podlega karze za usiłowanie, kto dobrowolnie odstapit od czynu lub zapobiegt skutkowi stanowiacemu znamię czynu zabronionego" - Ustawa z dnia 20 maja 1971 r. - Kodeks wykroczeń, Dz.U. 2019, poz. 821.

15 Zob. W. WróBel: Formy stadialne $i$ postacie zjawiskowe popetnienia przestępstwa (Warszawa, 17 maja 2006 r.) - Zapis dyskusji. W: Formy stadialne i postacie zjawiskowe popetnienia przestępstwa. Materiały III Bielańskiego Kolokwium Karnistycznego. Red. J. MajEwsKi. Torun 2007. 
dokonania czynu zabronionego, z czym zawsze wiąże się pewien rodzaj niebezpieczeństwa dla dóbr chronionych prawem. Natomiast usiłowanie nieudolne, będące wynikiem błędu co do przedmiotu lub środka nadającego się do popełnienia czynu zabronionego, charakteryzuje brak możliwości realizacji znamion danego przestępstwa, a w konsekwencji brak zagrożenia dla dóbr prawnych ${ }^{16}$. Przedstawionej konstatacji nie zmienia okoliczność, iż treść art. $13 \S 2$ k.k. nie zawiera pełnej charakterystyki znamion usiłowania nieudolnego. Przywołany przepis należy, co prawda, uzupełnić o elementy wyrażone $\mathrm{w}$ treści art. $13 \S 1$ k.k., jednak tylko $\mathrm{w}$ takim zakresie, $\mathrm{w}$ jakim dają się one pogodzić z istotą i specyfiką tejże instytucji. O ile zatem usiłowanie udolne wiąże się z obiektywnym zmierzaniem do dokonania czynu zabronionego, o tyle usiłowanie nieudolne stanowi zachowanie zmierzające bezpośrednio do dokonania tylko według subiektywnego przekonania sprawcy ${ }^{17}$.

$\mathrm{Na}$ marginesie prowadzonych tu rozważań należy wskazać, że powyższy wywód dość dobrze obrazuje kryterium rozgraniczające dwa omawiane typy usiłowania. Różnica między usiłowaniem udolnym a nieudolnym dotyczy bowiem obiektywnej możliwości lub niemożliwości dokonania czynu zabronionego i na tym polu należałoby poszukiwać swoistej cezury oddzielającej te formy stadialne przestępstwa. W tym kontekście może dziwić stosunkowo częste powoływanie się przez sądy na argumentację, iż „istota nieudolnego usiłowania polega na tym, że w odróżnieniu od usiłowania udolnego nie stwarza ono realnego zagrożenia dobra prawnego" ${ }^{18}$.

${ }^{16}$ Por. J. Majewski, który podnosi, iż wniosek, że usiłowanie nieudolne nie powoduje żadnego zagrożenia dla dóbr prawnych, jest nadmiernym uproszczeniem całej sprawy. W celu poparcia swojej tezy autor posługuje się przykładem sprawcy, który w zamiarze spowodowania trwałego paraliżu kończyn u ofiary podaje jej odpowiedni trujący środek chemiczny, jednak w dawce zbyt małej, aby taki skutek wywołać u dorosłego człowieka, w konsekwencji czego wszystko kończy się przejściowym, krótkotrwałym rozstrojem zdrowia pokrzywdzonego. Taki stan rzeczy J. Majewski kwalifikuje jako przypadek usiłowania nieudolnego przestępstwa przeciwko zdrowiu, określonego w art. $156 \S 1$ k.k., przy którym dochodzi jednak do zagrożenia zdrowia ofiary - zob. J. Majewski: O różnicy i granicy między usiłowaniem udolnym a nieudolnym. W: Formy stadialne..., s. 47 i nast. Należy także odnotować, że w doktrynie podnosi się, iż elementem odróżniającym usiłowanie udolne od nieudolnego są różne powody braku dokonania czynu zabronionego. Zob. więcej: P. ZAKRZEWski: Przestanka „bezpośredniości zmierzania” przy usiłowaniu nieudolnym a tzw. usitowanie bezwzględnie nieudolne. CPKNP 2001, z. 4, s. 85 i nast.

17 A. LIsZEWsKa: Formy stadialne popetnienia czynu zabronionego. W: System Prawa Karnego. Nauka o przestępstwie. Zasady odpowiedzialności. T. III. Red. R. DęBSKI. Warszawa 2017, s. 807-808. Wydaje się zatem, że przesłanki usiłowania udolnego należy interpretować w duchu obiektywnym, podczas gdy elementy konstytuujące figurę usiłowania nieudolnego mają wyraźnie subiektywny charakter.

18 Tak na przykład stwierdził SA w Katowicach w wyr. z dnia 26 listopada 2018 r., II AKa 237/18. Biul. SAKa 2019/1/15. W tożsamy sposób wypowiedział się SA w Lublinie 
Prawdą jest, że usiłowanie udolne - z uwagi na obiektywną możliwość realizacji znamion przestępstwa - wiąże się z pewnym zagrożeniem dla dóbr chronionych prawem, jednak wskazywanie kwantum owego niebezpieczeństwa jawi się o tyle niezasadnie, że art. 13 k.k. można relacjonować do każdego typu czynu zabronionego ${ }^{19}$, w tym również do przestępstw abstrakcyjnego narażenia na niebezpieczeństwo. Wskazana kategoria czynów posiada z kolei tę swoistość, że in concreto nie musi wiązać się z realnym zagrożeniem dla dóbr prawnych ${ }^{20}$. Tym samym utożsamianie instytucji usiłowania udolnego z realnością i konkretnością zagrożenia dla dóbr prawnych prowadziłoby do mało przekonującego wniosku, iż w odniesieniu do niektórych typów czynów zabronionych ta forma stadialna przestępstwa charakteryzuje się większą intensywnością zamachu na dobro prawne aniżeli samo jego dokonanie ${ }^{21}$. Jak trafnie wskazuje się w doktrynie, przesłanką konstrukcyjną usiłowania nie jest zachowanie odpowiedniego stosunku między zachowaniem usiłowanym a naruszeniem dobra prawnego, ale między zachowaniem usiłowanym

w wyr. z dnia 25 września 2013 r., II AKa 131/13. LEX nr 1381450. Za co najmniej dyskusyjną należy również uznać definicję usiłowania nieudolnego przedstawioną przez SO w Krakowie, który w wyr. z dnia 20 marca 2015 r. stwierdził, iż „[...] Samo powzięcie zamiaru nie jest bowiem penalizowane przez polską ustawę karną, zaś usiłowanie zachodzi jedynie wtedy, gdy sprawca podjął czynności będące bezpośrednim zmierzaniem do popełnienia czynu zabronionego - choćby nawet z przyczyn obiektywnych i od sprawcy niezależnych nie doszło do bezpośredniego zagrożenia tego dobra (usiłowanie nieudolne)". Wyr. SO w Krakowie z dnia 20 marca 2015 r., IV Ka 1058/14. Źródło: http://orzeczenia. ms.gov.pl/details/\$N/152010000002006_IV_Ka_001058_2014_Uz_2015-04-21_002 [dostęp: 22.03.2021].

${ }^{19}$ Jak trafnie wskazał J. Giezek: „Przede wszystkim należy zwrócić uwagę, że usiłowanie nie egzystuje samodzielnie, lecz - jako forma stadialna popełnienia przestępstwa uregulowana w części ogólnej Kodeksu karnego - czerpie swój sens dopiero w relacji do określonego typu czynu zabronionego. Nie ma bowiem usiłowania jako takiego, gdyż w każdym konkretnym przypadku usiłujący sprawca zmierza do popełnienia konkretnego przestępstwa" - J. GIEzeK: Formy popetnienia przestępstwa. W: Kodeks karny. Część ogólna. Komentarz. Red. IDEM. Warszawa 2007, s. 133.

${ }^{20}$ Należy bowiem wskazać, że podstawy karalności przestępstw z abstrakcyjnego narażenia na niebezpieczeństwo bardzo często definiowane są przy pomocy teorii generalnego niebezpieczeństwa. Zakłada ona, że podstawą karnoprawnego zakazu nie jest indywidualna szkodliwość pojedynczego zachowania, ale szkodliwość klasy, do której ono należy. Tym samym dane zachowanie sprawcy nie musi in concreto wykazywać się jakąkolwiek zdatnością do wywołania ujemnego skutku. Więcej na ten temat zob. D. GRUSZECKA: Ochrona dobra prawnego na przedpolu jego naruszenia. Warszawa 2012, s. 258 i nast.

${ }^{21}$ Tym samym należy przyznać rację D. Gruszeckiej, która wskazała, iż: „Do stworzenia realnego, konkretnego czy bezpośredniego niebezpieczeństwa dla dobra wskutek usiłowania popełnienia danego czynu nie dochodzi przecież tam, gdzie sam czyn dla swego dokonania nie wymaga stworzenia realnego, konkretnego czy bezpośredniego niebezpieczeństwa dla dobra prawnego - np. właśnie przy przestępstwach z abstrakcyjnego narażenia na niebezpieczeństwo" - Ibidem, s. 330. 
a dokonaniem ${ }^{22}$. Konkludując, należy jeszcze raz powtórzyć, że dyferencji między usiłowaniem udolnym a nieudolnym należy poszukiwać przede wszystkim w elemencie możliwości lub niemożliwości dokonania czynu zabronionego, ocenianym rzecz jasna ex ante. Wyznaczanie linii granicznej wedle stopnia zagrożenia dla dobra prawnego nasuwa bowiem rozwiązania, które w szerszym kontekście normatywnym wydają się dalece nieintuicyjne.

\section{Znamię bezpośredniości jako moment wyznaczający początek usiłowania}

Kwestia niezwykle sporna $w$ judykaturze dotyczy interpretacji znamienia „bezpośredniości” jako relewantnego prawnie punktu wyznaczającego początek usiłowania. Wskazany problem jest o tyle istotny, że odmienne postrzeganie owego elementu skutkuje przyjmowaniem przez sądy różnych kwalifikacji prawnych $\mathrm{w}$ zakresie tożsamego stanu faktycznego ${ }^{23}$. Taka praktyka nie służy z kolei utrwalaniu zasady pewności prawa oraz budowaniu jednolitej linii orzeczniczej, która ma niebagatelne znaczenie zwłaszcza tam, gdzie przebiega granica kryminalizacji ${ }^{24}$. Należy bowiem zauważyć, że im szersza wykładnia znamienia bezpośred-

22 Ibidem, s. 330 i nast.

${ }^{23}$ Jako przykład może choćby posłużyć wyr. SA we Wrocławiu z dnia 24 kwietnia 2013 r., w którym zachowanie sprawcy polegające na montażu kamery i skimmera, jego kalibracji oraz zebrania danych z oryginalnych kart pamięci skimmera zostało zakwalifikowane przez sąd I instancji jako usiłowanie popełnienia przestępstwa określonego w art. 310 k.k., natomiast rozpoznający sprawę sąd II instancji uznał, że działanie oskarżonego zatrzymało się na etapie przygotowania - wyr. SA we Wrocławiu z dnia 24 kwietnia 2013 r., II AKa 108/13. LEX nr 1322854. Kolejną egzemplifikacją postawionej tezy jest orzecz. SN z dnia 27 marca 2013 r. Dotyczy ono stanu faktycznego, który najpierw przez sądy I oraz II instancji został zakwalifikowany jako karalne usiłowanie przestępstwa stypizowanego w art. 291 k.k., natomiast SN - na skutek wniesionej kasacji - wyrok ten uchylił i sprawę przekazał do ponownego rozpoznania, wskazując, iż należyte jej rozstrzygnięcie wymaga ponownego rozważenia, czy zachowanie sprawcy rzeczywiście stanowiło bezpośrednie zmierzanie do dokonania czynu zabronionego. Wyr. SN z dnia 27 lutego 2013 r., IV KK 288/12. LEX nr 1294452.

${ }^{24}$ Dla porządku należy bowiem przypomnieć, że o ile przygotowanie jest karalne tylko wtedy, gdy ustawa tak stanowi, o tyle usiłowanie jest karalne zawsze. Tym samym odpowiedzialność karna bardzo często rozpoczyna się właśnie od formy stadialnej usiłowania popełnienia przestępstwa. Trzeba także zasygnalizować, że posługiwanie się przez ustawodawcę znamieniem ocennym, które generuje tyle rozbieżności w zakresie jego interpretacji, może pozostawać sprzeczne z postulatem takiego formułowania przepisów represyjnych, aby jednostka nie miała wątpliwości, że jej zachowanie w konkretnych okolicznościach naraża ją na odpowiedzialność karną. Zob. wyr. TK z dnia 17 lipca 2014 r., SK 35/12. OTK-A 2014/7/74. Na niekorzystne konsekwencje związane z pozostawieniem 
niości, tym większe ramy zostaną zakreślone dla formy stadialnej usiłowania, która zawsze prowadzi do odpowiedzialności karnej, i odwrotnie węższa interpretacja powyższego znamienia będzie skutkować częstszym kwalifikowaniem określonych zachowań jako „tylko wyjątkowo” karalnych czynności przygotowawczych ${ }^{25}$. Tym samym potrzeba wypracowania stosunkowo precyzyjnych oraz czytelnych kryteriów bezpośredniości ma w pełni zasadny charakter.

Rozbieżności w judykaturze koncentrują się zwłaszcza wokół pytania, które zachowania posiadają cechę bezpośredniości zmierzania do dokonania i wedle jakich elementów owa bezpośredniość winna być oceniana. Przykładem tego jest diametralnie różne postrzeganie przez sądy tych form aktywności sprawcy, które sprowadzają się do przyjścia na miejsce planowanego czynu i wyczekiwanie odpowiedniego momentu przeprowadzenia zamachu na dobro prawne. Podobne kontrowersje dotyczą zachowań polegających na obserwowaniu czy też wyczekiwaniu na wytypowaną ofiarę. W postanowieniu z dnia 23 maja 2007 r. Sąd Najwyższy przyjął, iż czynności „zwiadowcze” ukierunkowane na ustalenie taktyki oraz określenie najlepszego momentu przeprowadzenia ataku wykraczają poza ramy przygotowania i stanowią postać bezpośredniego zmierzania do dokonania czynu zabronionego ${ }^{26}$. Na podobnym stanowisku stanął Sąd Najwyższy w postanowieniu z dnia 1 kwietnia 2005 r., opowiadając się za szeroką interpretacją znamienia bezpośredniości i wskazując, że przyjście oskarżonego pod dom ofiary i oczekiwanie na jej nadejście słusznie zostało przez sądy I oraz II instancji zakwalifikowane jako karalny etap usiłowania dokonania przestępstwa rozboju ${ }^{27}$. W podobnym duchu wypowiedział się Sąd Apelacyjny w Szczecinie, który w orzeczeniu z dnia 15 kwietnia 2013 r. podniósł, iż dwukrotne udanie się przez sprawców pod stację benzynową w celu dokonania napadu rabunkowego mieści się $\mathrm{w}$ zakresie formy stadialnej usiłowania ${ }^{28}$. Natomiast na zupełnie odmien-

oceny bezpośredniości sędziowskiej intuicji zwraca również uwagę J. GIEzeK: Formy stadialne..., s. 46 i nast.

${ }^{25}$ W tym kontekście należy również zauważyć, że rozciąganie znamienia bezpośredniości w kierunku czynności przygotowawczych będzie skutkować częstszym kwalifikowaniem określonych stanów faktycznych jako usiłowania udolnego, pomimo że uwzględnienie późniejszych okoliczności wskazywałoby na niemożność dokonania czynu, a tym samym nieudolność usiłowania.

26 Post. SN z dnia 23 maja 2007 r., V KK 265/06. OSNKW 2007/7-8/58.

27 Post. SN z dnia 1 kwietnia 2005 r., IV KK 309/04. OSNKW 2005/9/79.

${ }^{28}$ Wyr. SA w Szczecinie z dnia 15 kwietnia 2013 r., II AKa 36/13. LEX nr 1313431. Nieco mniej kategorycznie wypowiedział się inny SA w Szczecinie, który w wyr. z dnia 22 maja 2014 r. przyjął, iż „Wydaje się, że przyjście pod dom z zamiarem dokonania włamania - zgodnie z wcześniej opracowanym planem - oraz z narzędziami służącymi do popełnienia przestępstwa, a następnie odstąpienie od realizacji tego zamiaru z przyczyn 
nym stanowisku stanął Sąd Apelacyjny w Katowicach, który w wyroku z dnia 25 kwietnia 2019 r. kategorycznie przyjął, że przybycie sprawcy na miejsce planowanego czynu oraz obserwowanie ofiary stanowi klasyczną czynność przygotowawczą do popełnienia czynu zabronionego ${ }^{29}$. W uzasadnieniu przywołanego wyroku sąd ten wskazał, iż zachowania posiadające cechę bezpośredniości muszą być w sposób instrumentalny powiązane z czynnością główną, stanowiącą znamię czasownikowe danego typu czynu zabronionego. Jednocześnie wyjaśnił, że czynności instrumentalne to takie przejawy aktywności sprawcy, które poprzedzają lub w praktyce życia towarzyszą danej czynności głównej. Jeżeli w danym miejscu i czasie nie zaistniała ani czynność główna opisana w przepisie typizującym (np. uderzenie kogoś w twarz jako forma przemocy), ani żadna instrumentalnie z nią związana czynność poboczna (np. zbliżenie się szybkim krokiem do danej osoby, by zadać jej cios), to zachowania sprawcy podjęte $\mathrm{w}$ fazie poprzedzającej wykonanie właściwej czynności sprawczej danego typu przestępstwa, np. przed przystąpieniem do „przemocowego" aktu rozboju z art. 280 § 1 lub 2 k.k., nie mogą zostać uznane za bezpośrednie zmierzanie do dokonania w rozumieniu art. $13 \S 1$ k.k. ${ }^{30}$.

Wydaje się, że słuszny jest ten kierunek interpretacyjny, który cechę bezpośredniości odnosi do zachowań wykazujących pewien przedmiotowy związek ze znamieniem czasownikowym danego typu czynu zabronionego. Przesłankę bezpośredniego zmierzania do dokonania należy bowiem interpretować w duchu obiektywistycznym, co implikuje konstatację, że na podstawie samych elementów przedmiotowych możliwe jest wnioskowanie o ujemnej wartości zachowania sprawcy ${ }^{31}$. Jak było to sygnalizowane wcześniej, sformułowanie „bezpośrednio” oznacza

od sprawcy niezależnych, przekracza ramy czynności przygotowawczych i jest działaniem zmierzającym bezpośrednio do urzeczywistnienia tego zamiaru" - wyr. SA w Szczecinie z dnia 22 maja 2014 r., II AKa 83/14. LEX nr 1506297.

${ }^{29}$ Wyr. SA w Katowicach z dnia 25 kwietnia 2019 r., II AKa 415/17. LEX nr 2728176.

30 Należy zauważyć, że w podobny sposób wypowiedział się SA w Lublinie, który w wyr. z dnia 21 marca 2017 r. wskazał, iż „Jeżeli sprawcy realizację swojego zamiaru zakończyli na etapie obserwacji lokalu, w którym zamierzali dokonać rozboju, a więc nie weszli do lokalu, nie założyli (nie rozwinęli na twarze) kominiarek, nikomu nie okazali, że jeden z nich posiada broń palną, to swoim zachowaniem zmierzali do dokonania rozboju, ale nie bezpośrednio w rozumieniu art. 13 § 1 k.k." - wyr. SA w Lublinie z dnia 21 marca 2017 r., II AKa 17/17. LEX nr 2279554.

${ }^{31} \mathrm{Na}$ dominujące znaczenie elementów przedmiotowych przy znamieniu bezpośredniości wskazywał również M. Siewierski, który podnosił, iż „przeniesienie punktu ciężkości na wypełnienie obiektywnych znamion przestępstwa zapobiega dowolności ocen i sprowadza kwestię do faktów obiektywnie istniejących, a więc sprawdzalnych, co zapobiega przesadzie w ocenie przez organ orzekający zachowania się sprawcy jako wpisującego się w ramy usiłowania" - M. SIEWIERSKI: Usiłowanie a przygotowanie wedtug kodeksu karnego. Pal. 1972, nr 5, s. 29. 
„wprost”, „bez ogniw pośrednich”, co zdaje się sugerować pewną „bliskość" do dokonania stanowiącego ostatnie stadium w pochodzie przestępstwa. Powyższe oznacza, iż na podstawie zewnętrznych elementów czynu istnieje możliwość ustalenia, do jakiego przestępstwa rodzajowego zmierzał sprawca. Za trafne należy zatem uznać poglądy tych przedstawicieli doktryny, którzy podnoszą, iż bezpośrednie zmierzanie zachodzi w sytuacji, gdy na podstawie okoliczności zewnętrznych zdarzenia można określić kierunek działania sprawcy. Ów kierunek powinien wskazywać na zaatakowane przez niego dobro, sposób zaatakowania tego dobra czy przedmiot czynności wykonawczej ${ }^{32}$. Stanowisko odmienne prowadzi bowiem do swoistego rozciągania omawianej formy stadialnej, która swoim zakresem obejmuje niemal każde zmierzanie (a zatem nie tylko bezpośrednie) do dokonania czynu zabronionego ${ }^{33}$. Początek usiłowania wyznaczają wówczas takie momenty, które same w sobie, a zatem bez uwzględniania elementów wolicjonalnych, nie wskazują na jakiekolwiek zagrożenie dla dóbr chronionych prawem. W konsekwencji należałoby zaakceptować tezę, że w wielu przypadkach warunkiem bezprawności usiłowania jest określone nastawienie sprawcy, bez którego nie można sensownie uzasadnić kryminalizacji jego zachowania. Nie ulega bowiem wątpliwości, że działanie sprawców polegające chociażby na wejściu do klubu celem ustalenia taktyki ataku ${ }^{34}$ prima facie jawi się jako w pełni legalne. Subiektywistyczna interpretacja znamienia bezpośredniości ma także określone przełożenie na praktykę stosowania prawa, jak również przestrzeganie zasady nullum crimen sine lege. Trzeba bowiem zauważyć, że brak w konkretnym wypadku obiektywnych okoliczności zdarzenia powoduje, że organ orzekający ma pełną dowolność w zakresie rekonstruowania zamiaru sprawcy, a w konsekwencji dokonywania kwalifikacji prawnej jego czynu. Jak łatwo zauważyć, aktywność sprawcy sprowadzającą się do czatowania na ofiarę można rozpatrywać przez pryzmat co najmniej kilku przepisów określonych w części szczególnej Kodeksu

32 P. ZaKrzewski: Przesłanka „bezpośredniości zmierzania”..., s. 85.

33 Jak trafnie zauważa O. Sitarz, gdyby tak miało być, ustawodawca pominąłby element bezpośredniości w ustawowym opisie. O. Sitarz: Czynny żal..., s. 135.

${ }^{34}$ Zob. post. SN z dnia 23 maja 2007 r., w którym sąd ten przyjął, że „Nie ma więc wątpliwości, że wysłanie wytypowanych spośród siebie zwiadowców w celu ustalenia taktyki ataku, zapewnienia jego sprawności i skuteczności, zainicjowało czynności zmierzające już bezpośrednio do dokonania pobicia. [...]. Granica dzieląca stan abstrakcyjnego zagrożenia dla dobra prawnego od zagrożenia realnego została przekroczona. Rozpoczęła się karalna forma stadialna, w której «bezpośrednie zmierzanie» do dokonania czynu zabronionego (art. 13 § 1 k.k.) obejmuje całość zachowań wiodących wprost do wypełnienia jego znamion, stwarzających realne zagrożenie dla chronionego dobra prawnego, a nie wyłącznie ostatnie z tych zachowań, poprzedzające realizację czynności sprawczej czynu zabronionego" - Post. SN z dnia 23 maja 2007 r., V KK 265/06. OSNKW 2007/7-8/58. 
karnego ${ }^{35}$. Tym samym nie sposób wykluczyć sytuację, w której sprawcy zostanie przypisane przestępstwo cięższe aniżeli to, które rzeczywiście chciał popełnić. Nie ulega wątpliwości, że taka praktyka, prowadząca skądinąd do znacznych rozbieżności $\mathrm{w}$ orzecznictwie, nie sprzyja realizowaniu funkcji gwarancyjnej prawa karnego, jak również umacnianiu zasady zaufania obywateli do obowiązującego prawa ${ }^{36}$. Tym samym zachowania takie jak przyjście na miejsce czynu zabronionego, przeprowadzenie swoistego „rekonesansu otoczenia”, obserwowanie ofiary czy też ukrycie się i wyczekiwanie na nią należałoby raczej traktować jako czynności mające stworzyć warunki do przedsięwzięcia czynu zmierzającego bezpośrednio do dokonania, a nie jako karalny etap usiłowania ${ }^{37}$. Dopiero bowiem kolejne zachowanie, warunkowane nierzadko skutecznością przeprowadzonych uprzednio czynności rozpoznawczych, stanowi ogniwo bezpośrednio poprzedzające realizację przestępstwa, do którego popełnienia sprawca zmierzał. Wiązanie początkowego momentu usiłowania z bardziej zaawansowaną fazą działania sprawcy umożliwia również obiektywne ustalenie tego, do czego sprawca dążył oraz jakie dobro prawne swoim zachowaniem chciał naruszyć.

Powyższa propozycja rozumienia pojęcia bezpośredniości nawiązuje do formalno-obiektywnej koncepcji wykładni powyższego znamienia, która bezpośredniość odnosi do ustawowych znamion czynu zabronionego ${ }^{38}$.

${ }^{35}$ Nie ulega wątpliwości, że tego rodzaju zachowanie można zakwalifikować jako usiłowanie zabójstwa, kradzieży, rozboju, ale także jako usiłowanie przestępstwa np. zniewagi.

36 Zob. również G. RejMan: Usiłowanie..., s. 60.

37 Należy również wskazać, że zaproponowana tu kwalifikacja wymienionych form aktywności sprawcy jako czynności poprzedzających etap usiłowania pozostaje w pełni spójna z kodeksową definicją przygotowania, która została zadekretowana w art. 16 k.k. Zgodnie z dyspozycją przywołanego przepisu „Przygotowanie zachodzi tylko wtedy, gdy sprawca w celu popełnienia czynu zabronionego podejmuje czynności mające stworzyć warunki do przedsięwzięcia czynu zmierzającego bezpośrednio do jego dokonania, w szczególności w tymże celu wchodzi w porozumienie z inną osobą, uzyskuje lub przysposabia środki, zbiera informacje lub sporządza plan działania". Trzeba przy tym zauważyć, że czynności takie jak przyjście pod dom ofiary, obserwacja lokalu czy też wejście do niego celem ustalenia taktyki zamachu to typowa faza zbierania informacji, która expressis verbis wymieniona została w treści art. 16 k.k. Nie ulega zaś wątpliwości, że ustawowa definicja przygotowania współkształtuje granicę oddzielającą przygotowanie od usiłowania, a zatem musi być brana pod uwagę przy ustalaniu zakresu czynności objętych treścią art. 13 k.k. Więcej na ten temat zob. M. MAŁECKI: Przygotowanie do przestępstwa. Analiza dogmatycznoprawna. Warszawa 2016, s. 308 i nast.

${ }^{38} \mathrm{~W}$ doktrynie podnosi się również, iż koncepcja formalno-obiektywna ma dwa punkty odniesienia: 1. znamię czasownikowe typu czynu zabronionego; 2. określenie treści i granic przygotowania. O. Sitarz: Czynny żal..., s. 142. Dlatego tak ważne jest każdorazowe ustalenie znamion danego typu czynu zabronionego, do którego popełnienia zmierzał sprawca. 
Należy jednak wyraźnie zaznaczyć, że teoria ta nie oznacza konieczności zawężania etapu usiłowania do rozpoczęcia wykonania czynu zabronionego. Po pierwsze, ustawodawca nie formułuje takiego wymogu na gruncie regulacji ustawowej, po drugie zaś, w przypadku przestępstw formalnych początek wykonania oznaczałby w istocie jego dokonanie. Tym samym swoistym punktem odniesienia do oceny omawianej cechy bezprawności jest znamię czasownikowe danego przestępstwa, z położeniem akcentu na zachowanie poprzedzające jego realizację ${ }^{39}$. Takie kryteria bezpośredniości wydają się pozostawać spójne z literalnym brzmieniem przepisu art. 13 k.k., który powyższe znamię nakazuje relacjonować do dokonania (a zatem czynności wykonawczej danego typu przestępstwa). Z drugiej strony nie pozostawiają one zbyt dużej dowolności w zakresie oceny owej bezpośredniości, pozwalając tym samym na jednakowe kwalifikowanie zbliżonych stanów faktycznych ${ }^{40}$.

39 Tak trafnie SA we Wrocławiu w wyr. z dnia 14 lutego 2013 r., II AKa 4/13. LEX nr 1289606. W podobnym kierunku zmierzał chyba SA w Szczecinie, który w wyr. z dnia 3 marca 2016 r. wskazał, iż „Bezpośrednie zmierzanie do dokonania, jako znamię usiłowania, wiązać należy ze znamieniem czasownikowym danego typu czynu zabronionego. Znamię bezpośredniości jest spełnione, jeżeli w miejsce znamienia czasownikowego, występującego w danym typie, daje się wprowadzić - adekwatnie do rzeczywistości - bezpośrednie zmierzanie do dokonania" - wyr. SA w Szczecinie z dnia 3 marca 2016 r., II AKa 10/16. Legalis nr 1445853.

${ }^{40}$ Należy wskazać, że znamię bezpośredniości można również wykładać zgodnie z teorią materialno-obiektywną, skądinąd jeszcze częściej powoływaną w orzecznictwie, która odwołuje się do stopnia zagrożenia, jakie zachowanie sprawcy niesie dla dóbr chronionych prawem. I tak przygotowanie miałoby wiązać się z abstrakcyjnym niebezpieczeństwem dla dóbr prawnych, podczas gdy w usiłowanie wpisane byłoby niebezpieczeństwo realne. Zob. post. SN z dnia 20 stycznia 2017 r., IV KK 438/16. LEX nr 2224613 czy też wyr. SN z dnia 8 marca 2006 r., IV KK 415/05. LEX nr 183071. Już wcześniej wskazywałam jednak, że wprowadzanie linii granicznej między formami stadialnymi przestępstwa na podstawie powyższego kryterium jest zbyt daleko idącym uproszczeniem. Po pierwsze podział ten sugeruje, jakoby usiłowanie zawsze stanowiło przestępstwo konkretnego narażenia na niebezpieczeństwo, po drugie zaś usiłowanie możliwe jest również w odniesieniu do tej kategorii czynów zabronionych, które in concreto nie wiążą się z konkretnym czy też realnym zagrożeniem dla dóbr prawnych. Poza tym należy wspomnieć, że kryteria wyprowadzane z koncepcji materialno-obiektywnej są raczej mgliste, a w konsekwencji nie przybliżają do odpowiedzi na pytanie, co należy rozumieć pod pojęciem bezpośredniego zmierzania. Jeden organ orzeczniczy uzna bowiem, że dane zachowanie stanowi już realne zagrożenie dla dóbr prawnych, drugi z kolei przyjmie, iż w istocie zachowanie sprawcy nie przekształciło się jeszcze z zagrożenia abstrakcyjnego $\mathrm{w}$ realne. 


\section{Charakter znamienia usiłowania nieudolnego w postaci przedmiotu nadającego się do popełnienia na nim czynu zabronionego}

Treść art. 13 § 2 k.k. określającego karalność usiłowania nieudolnego prowadzi do wniosku, że elementem konstytuującym tę formę stadialną przestępstwa jest błąd sprawcy, który musi przybrać postać błędu co do przedmiotu lub środka nadającego się do popełnienia czynu zabronionego. Trzeba jednak zauważyć, że ustawodawca nie dostarczył żadnych wskazówek, według których należałoby interpretować powyższe znamiona, w tym zwłaszcza nie wskazał, czy znamię przedmiotu nadającego się do popełniania na nim czynu zabronionego należy rozumieć w sposób obiektywny czy subiektywny. Powyższe jest zapewne jednym z czynników powodujących daleko idące zróżnicowanie orzecznictwa, które przejawia się niezwykle wyraźną polaryzacją stanowisk w tym zakresie. Część sądów orzekających przyjmuje bowiem, że usiłowanie nieudolne zachodzi wtedy, gdy nie występują jakiekolwiek przedmioty nadające się do popełnienia czynu zabronionego, którego popełnienie było objęte zamiarem sprawcy. Tym samym ukierunkowanie zamiaru sprawcy na konkretny desygnat znamienia przedmiotu czynności wykonawczej nie ma znaczenia dla przyjęcia, że dochodzi do usiłowania nieudolnego ${ }^{41}$. Natomiast stanowisko przeciwne, również bardzo często reprezentowane w orzecznictwie, zakłada, iż brak przedmiotu nadającego się do popełnienia na nim czynu zabronionego oznacza tylko taki przedmiot, na który ukierunkowany jest zamiar sprawcy, bez względu na to, czy istnieją inne przedmioty potencjalnie nadające się do popełnienia na nich czynu zabronionego ${ }^{42}$. Należy również wskazać, iż uchwała Sądu Najwyższego ${ }^{43}$ z dnia 19 stycznia 2017 r. podjęta w składzie 7 sędziów raczej nie przyczyni się do usunięcia powstałych rozbieżności, gdyż twierdzenia $\mathrm{w}$ niej zawarte pozostają wzajemnie sprzeczne ${ }^{44}$. Z jednej strony Sąd Najwyższy opowiada się bowiem za obiektywizowaniem znamienia przedmiotu nadającego się do popełnienia na nim czynu zabronionego, z drugiej zaś wskazuje

41 Tak np. wyr. SA w Katowicach z dnia 28 lutego 2002 r., II AKa 549/01. LEX nr 56778 czy też wyr. SA w Białymstoku z dnia 18 czerwca 2015 r., II AKa 73/15. LEX nr 1439168.

42 Tak chociażby wyr. SA w Łodzi z dnia 21 lutego 2002 r., II AKa 17/02. LEX nr 84233 czy też wyr. SA we Wrocławiu z dnia 25 stycznia 2013 r., II AKa 400/12. LEX nr 1289607.

${ }^{43}$ Uchw. SN z dnia 19 stycznia 2017 r., I KZP 16/16. OSNKW 2017/3/12.

${ }^{44}$ Należy wskazać, że przywołana uchwała wywołała również spore rozbieżności w piśmiennictwie. Zob. K. Kмąк: Glosa do uchwaty SN z dnia 19 stycznia 2017 r., I KZP 16/16. Prok. i Pr. 2017, nr 6, s. 156-167 - glosa krytyczna; A. Jezusek: Glosa do uchwaty SN z dnia 19 stycznia 2017 r., I KZP 16/16. Prok. i Pr. 2017, nr 4, s. 151-166. - glosa krytyczna; D. KraKowiaK: Usiłowanie nieudolne z uwagi na brak przedmiotu a strona podmiotowa czynu usiłowanego. Glosa do uchwaty SN z dnia 19 stycznia 2017 r., I KZP 16/16. LEX/el. 2017 - glosa aprobująca. 
na doniosłą rolę zamiaru w procesie przypisywania odpowiedzialności karnej jako elementu limitującego jej zakres ${ }^{45}$. Tym samym wydaje się, że nadal nierozstrzygnięty pozostaje spór, w jaki sposób zakwalifikować zachowanie sprawcy rozboju zmierzającego do zabrania konkretnego mienia pokrzywdzonemu, który jednak mienia tego nie posiada, choć jednocześnie dysponuje innym mieniem w ogóle nadającym się do zaborujako usiłowanie udolne czy też nieudolne z uwagi na brak przedmiotu nadającego się do popełnienia na nim czynu zabronionego ${ }^{46}$. Kwestia ta ma o tyle istotne znaczenie, że rozgranicza dwa typy usiłowań, co z kolei wiąże się ze stosowaniem innych instytucji materialnoprawnych, w tym m.in. nadzwyczajnego złagodzenia kary, odstąpienia od jej wymierzenia czy też przewidzianego w art. $15 \S 1$ k.k. czynnego żalu skutkującego niepodleganiem karze.

W tym miejscu należy wspomnieć o mieszanej koncepcji J. Giezka, która stanowi połączenie dwóch skrajnych punktów widzenia - obiektywnego i subiektywnego (autor ten proponuje dokonywanie swoistej obiektywizacji oceny subiektywnej). Istota wskazanej teorii polega na tym, że w sytuacji, gdy sprawca odstępuje od dokonania z uwagi na okoliczność, iż przedmiot czynności wykonawczej nie spełnia jego oczekiwań, należałoby odwołać się do wzorca racjonalnie oraz pragmatycznie zachowującego się sprawcy przestępstwa. Z tego powodu - zdaniem J. Giezka - nie może dziwić fakt rezygnacji z dokonania zaboru monety pięciozłotowej, skoro nie jest ona przedmiotem, dla którego w sensie obiektywnym „warto" byłoby dopuszczać się rozboju ${ }^{47}$.

${ }^{45}$ W uzasadnieniu wskazanej uchwały SN skonstatował, iż „Nie można pociągać sprawcy do odpowiedzialności karnej za usiłowanie nieudolne ponad granice jego umyślności. Te zaś wyznacza zamiar sprawcy, rozumiany jako zachowanie ukierunkowane na osiagnnięcie określonego celu i sterowanie tym zachowaniem. Nie ma zatem podstaw do nałożenia odpowiedzialności karnej za przestępstwo umyślne w takim zakresie, w jakim nie byłoby ono objęte zamiarem sprawcy". Natomiast jej teza brzmi następująco: „Zawarte w art. $13 \S 2$ k.k. wyrażenie: «brak przedmiotu nadającego się do popełnienia na nim czynu zabronionego» oznacza brak takiego przedmiotu, który należy do zbioru desygnatów znamienia przedmiotu czynności wykonawczej typu czynu zabronionego, do którego popełnienia zmierza sprawca".

46 To właśnie taki problem stanowił punkt wyjścia do podjęcia przywołanej uchwały, jak również uchwały podjętej przez najwyższą instancję kilkanaście lat wcześniej, w której opowiedziano się za subiektywistycznym rozumieniem znamienia przedmiotu nadającego się do popełnienia na nim czynu zabronionego. Zob. Uchw. SN z dnia 20 listopada 2000 r., I KZP 36/00. OSNKW 2001/1-2/1. Wskazany problem powstał na kanwie tych przypadków, w których osoba zmierzająca do przywłaszczenia danej rzeczy odstępuje od dokonania zamierzonego czynu, ponieważ okazuje się, że znajdujący się w zasięgu jej możliwości sprawczych przedmiot nie posiada pożądanych przez nią cech.

47 J. GIEZeK: Glosa do uchwały Sądu Najwyższego z dnia 20 listopada 2000 r., I KZP 36/00. Prok. i Pr. 2001, nr 9, s. 105 i nast. 
Przyrównywanie zachowania sprawcy do tak skonstruowanego wzorca może jednak budzić pewne zastrzeżenia z punktu widzenia praktyki judykacyjnej. Przegląd orzecznictwa prowadzi bowiem do jednoznacznego wniosku, że sprawcy niejednokrotnie dopuszczają się przestępstw z niezwykle błahych powodów. W charakterze egzemplifikacji warto przytoczyć choćby wyrok Sądu Okręgowego w Łodzi z dnia 17 października 2016 r. $^{48}$, który rozpoznawał sprawę oskarżonego o usiłowanie rozboju w celu zaboru kwoty 5 zł, czy też przywoływany już wyrok Sądu Apelacyjnego we Wrocławiu z dnia 25 stycznia 2013 r. $^{49}$ rozpatrującego sprawę oskarżonego o usiłowanie rozboju w celu zaboru kwoty w wysokości 2 zł. Tym samym jako zasadne jawi się pytanie, co należy rozumieć pod pojęciem rozsądnego i pragmatycznie zachowującego się sprawcy, jak również - jaka kwota mogłaby okazać się satysfakcjonująca z jego punktu widzenia.

Wydaje się, że formułując próbę odpowiedzi na pytanie dotyczące charakteru znamienia przedmiotu nadającego się do popełnienia na nim czynu zabronionego, należy poczynić kilka uwag natury ogólnej. W pierwszej kolejności trzeba zauważyć, że usiłowanie nieudolne stanowi figurę prawną, której bezprawność, a w konsekwencji karalność jest niemal całkowicie uzależniona od elementu subiektywnego. Bez ustalenia stosunku intelektualno-psychicznego sprawcy do popełnianego czynu z uwagi na obiektywny brak możliwości dokonania - niemożliwe byłoby przesądzenie ujemnej wartości jego zachowania. Tym samym to elementy podmiotowe wyznaczaja pewne granice, w ramach których odbywa się prawnokarne wartościowanie czynu sprawcy, gdyż to one stanowią źródło niebezpieczeństwa dla dóbr chronionych prawem. Należy również wskazać, że prawidłowe zrekonstruowanie zamiaru oznacza ustalenie nie tylko tego, co sprawca wie, ale również czego chce i do czego zmie$\mathrm{rza}^{50}$. Jako truizm jawi się stwierdzenie, że sprawca najczęściej nie chce po prostu zabić czy ukraść, gdyż jego aktywność ukierunkowana jest na konkretny obiekt w postaci zindywidualizowanej osoby lub rzeczy. Tym samym ustalenie, że sprawca przystąpił do realizacji swojej przestępczej woli, której urzeczywistnienie nie było jednak możliwe z uwagi na brak przedmiotu objętego jego zamiarem, wydaje się przesądzać, iż w sprawie

48 Wyr. SO w Łodzi z dnia 17 października 2016 r., V Ka 547/16. Źródło: http:// orzeczenia.ms.gov.pl/details/\$N/152510000002506_V_Ka_000547_2016_Uz_201610-17_001 [data dostępu: 22.03.2021]. Należy również wskazać, że np. wyrokiem SO w Słupsku z dnia 5 października 2016 r. sprawca został skazany za usiłowanie rozboju w celu zaboru piwa - wyr. SO w Słupsku z dnia 5 października 2016 r., II K 37/16. Źródło: https://www.saos.org.pl/judgments/251294 [data dostępu: 22.03.2021].

49 Wyr. SA we Wrocławiu z dnia 25 stycznia 2013 r., II AKa 400/12. LEX nr 1289607.

50 J. GIezeK: Świadomość sprawcy czynu zabronionego. Warszawa 2013, s. 178. 
doszło do realizacji znamion usiłowania nieudolnego (do naruszenia normy sankcjonowanej i sankcjonującej tej formy stadialnej przestępstwa). Ewentualna modyfikacja zachowania sprawcy, o której Sąd Najwyższy wprost wspominał w uzasadnieniu omawianej uchwały ${ }^{51}$, umożliwiająca popełnienie czynu zabronionego określonego typu stanowi $\mathrm{w}$ istocie kolejne przestępstwo, u podstaw którego leży odmienny od poprzedniego zamiar jego popełnienia. Sprawca na skutek diagnozowania tego, co wcześniej stanowiło wyłącznie przedmiot jego prognozy (np. orientuje się, że wbrew wcześniejszym wyobrażeniom jego ofiara nie ma pieniędzy, ale jest w posiadaniu złotego zegarka), na nowo kształtuje procesy intelektualno-wolicjonalne, od których przebiegu zależy realizacja znamion nowego już przestępstwa.

Ponadto nie wolno przejść do porządku nad tym, że każdy ustawowy opis przestępstwa składa się z elementów przedmiotowych oraz podmiotowych i dopiero łączna ich realizacja uzasadnia pociągnięcie danej osoby do odpowiedzialności karnej. Tym samym zamiar współokreśla typ czynu zabronionego, obligując organ orzekający do skrupulatnej jego rekonstrukcji. Należałoby zatem postawić pytanie, czy pociąganie sprawcy do odpowiedzialności za usiłowanie udolne w sytuacji, w której jego działanie ukierunkowane było na konkretny nośnik dobra prawnego, nie prowadzi do wypaczenia funkcji zamiaru ${ }^{52}$. Odpowiedzialność karna przypisywana byłaby wówczas niejako w oderwaniu od tego, co stanowiło faktyczny przedmiot jego woli ${ }^{53}$.

51 W omawianej uchwale SN wskazał bowiem, że „brak przedmiotu nadającego się do popełnienia na nim czynu zabronionego należy pojmować dosłownie i jednoznacznie jako przeszkodę przesądzającą o tym, że sprawca zmierzający bezpośrednio do dokonania nie jest w stanie tak zmodyfikować swojego zachowania, by popełnienie czynu zabronionego określonego typu stało się możliwe”.

${ }_{52}$ Konsekwencją obiektywizowania znamienia przedmiotu nadającego się do popełnienia na nim czynu zabronionego byłoby pociąganie sprawcy do odpowiedzialności za usiłowanie udolne również wtedy, gdy zamierzał on pozbawić życia osobę X, jednak w pomieszczeniu, do którego się włamał, zamiast wytypowanej ofiary znajdowała się tylko osoba Y. Należy również wskazać na dość często przywoływaną w doktrynie wypowiedź A. Wąska, który wskazał, iż „Klasycznym przykładem karalnego usiłowania nieudolnego kradzieży jest sięgnięcie przez złodzieja [...] do cudzej kieszeni, która jednak okazała się pusta [...]. Nie jest tu istotne, czy niedoszła ofiara kradzieży miała gdzieś indziej schowane pieniądze, czy miała coś innego, co mogłoby być przedmiotem kradzieży. Gdyby to miało być tutaj istotne, sprawca mógłby się dopuścić usiłowania nieudolnego przestępstwa kradzieży tylko do gołej osoby, i to tylko wtedy, gdy w pobliżu jej nie znajdowały się jej części garderoby lub inne rzeczy." - A. WĄSEK: Glosa do uchwały SN, sygn. I KZP 36/00. OSP 2001, nr 4, s. 174.

${ }^{53}$ Taka praktyka może również skutkować oczywistymi paradoksami na etapie przypisywania odpowiedzialności karnej, gdzie przyjęta kwalifikacja prawna w żaden sposób nie koresponduje z dokonanym opisem czynu zabronionego. Przykładem powyższego jest 
Należy również wskazać, że, jak trafnie przyjmuje się w doktrynie, nośnikiem zagrożenia dla dóbr prawnych jest wola człowieka, która w dalszej kolejności uruchamia pewne przebiegi przyczynowe ${ }^{54}$. Powyższe zdaje się uzasadniać konstatację, że brak obiektu ${ }^{55}$, na który ukierunkowany był zamiar sprawcy, oznacza w istocie brak zagrożenia dla dóbr prawnych. Z kolei wniosek o nieistnieniu niebezpieczeństwa dla wartości chronionej prawem automatycznie prowadzi w kierunku zakwalifikowania zachowania sprawcy jako karalnego usiłowania nieudolnego.

W charakterze podsumowania dotychczasowej części rozważań warto odnotować, że również literalne brzmienie przepisu przemawia za subiektywnym rozumieniem omawianego znamienia. Dyspozycja art. $13 \S 2$ k.k. jednoznacznie wskazuje bowiem na przedmiot nadający się do popełnienia na nim czynu zabronionego. Sformułowanie „na nim” wydaje się prowadzić do wniosku, że ustawodawca miał na myśli konkretny element rzeczywistości, na którym skoncentrowany jest zamiar sprawcy, a nie ogólnie ujętą wartość społeczną. Treść przywołanego przepisu nie dotyczy zatem abstrakcyjnego dobra prawnego w postaci życia, zdrowia czy mienia, ale odnosi się do jego zindywidualizowanego nośnika, na który ukierunkowane było działanie sprawcy. W konsekwencji stwierdzenie, że in concreto nośnik ten nie występuje, musi oznaczać spełnienie warunku w postaci braku przedmiotu nadającego się do popełnienia na nim czynu zabronionego ${ }^{56}$.

Powyższy wywód nasuwa wniosek, że znamię przedmiotu nadającego się do popełnienia na nim czynu zabronionego należy interpretować w sposób subiektywny. Konkluzja ta nie oznacza jednak konieczności przyjmowania usiłowania nieudolnego, kiedy obiekt, na którym sprawca koncentruje swój zamiar, co prawda, istnieje, lecz nie spełnia jego ocze-

chociażby wyr. SR w Szczecinku z dnia 4 września 2013 r., II K 203/13, w którym sąd uznał oskarżonych za winnych tego, że usiłowali dokonać rozboju w celu przywłaszczenia telefonu komórkowego i pieniędzy, lecz zamierzonego celu nie osiągnęli m.in. ze względu na fakt, że ich ofiara nie posiadała przy sobie telefonu komórkowego i pieniędzy, a następnie tak opisany czyn sąd ten zakwalifikował z art. $13 \S 1$ k.k., a zatem jako usiłowanie udolne przestępstwa rozboju. Zob. Wyr. SO w Koszalinie z dnia 15 listopada 2103 r., V Ka 704/13. Źródło: http://orzeczenia.ms.gov.pl/details/\$N/155510000002506_V_ Ka_000704_2013_Uz_2013-11-15_001 [dostęp: 22.03.2021].

54 Z. JĘDRZEJEwsKi: Bezprawie usitowania..., s. 177.

55 Obiekt, na którym skoncentrowane jest działanie sprawcy, stanowi bowiem materialny substrat dobra prawnego.

${ }^{56}$ Podobne wnioski formułuje J. Majewski, podkreślając, że zawarty w art. $13 \S 2$ k.k. zwrot „dokonanie (czynu zabronionego) jest niemożliwe” odnosi się do dokonania tego czynu zabronionego, który stanowi przedmiot zamiaru sprawcy. Więcej na ten temat zob. J. MAJEWsKI: O różnicy i granicy między usiłowaniem udolnym a nieudolnym. W: Formy stadialne..., s. 36 i nast. 
kiwań. Jako trafne jawią się poglądy tych przedstawicieli nauki, którzy wskazują, że inaczej należy ocenić okoliczność, kiedy różnica między rzeczami obiektywnie nadającymi się do zaboru a innymi przedmiotami objętymi zamiarem sprawcy jest ilościowa, a inaczej, kiedy ma ona charakter jakościowy ${ }^{57}$. W pierwszym przypadku istnieje bowiem konkretny obiekt rzeczywistości, na który sprawca ukierunkował swój zamach, co oznacza, że pomimo odmiennych wyobrażeń sprawcy co do właściwości danego przedmiotu jego zachowanie należy potraktować jako usiłowanie udolne ${ }^{58}$. Natomiast w drugim wypadku występuje brak przedmiotu czynności wykonawczej, który objęty był zamiarem sprawcy, co prowadzi do wniosku, iż przypisanie odpowiedzialności za usiłowanie udolne stanowiłoby wyjście poza granice jego umyślności ${ }^{59}$.

${ }_{57}$ M. MAŁECKI: Glosa do uchwaty SN z dnia 19 stycznia 2017 r., sygn. I KZP 16/16. OSP 2017, nr 7-8, s. 221 i nast. Jednocześnie autor wskazuje, że w przypadku, kiedy sprawca chce dokonać zaboru pieniędzy, należy uznać, iż moneta pięciozłotowa, do której miał on dostęp po zastosowaniu przemocy wobec ofiary, nawet jeśli nie spełnia jego oczekiwań, stanowi przedmiot nadający się do dokonania zaboru. Sprawca od początku był zainteresowany kradzieżą pieniędzy, które były w posiadaniu pokrzywdzonego i nadawały się do dokonania rozboju, bez względu na ich ilość. Natomiast w odniesieniu do różnicy jakościowej autor konstatuje, iż z faktu, że sprawca chce ukraść rower, nie wynika, ex ante, że zamiast roweru chce ukraść także inne przedmioty znajdujące się w danym miejscu.

${ }^{58}$ Należy jednak wskazać, że zachowanie sprawcy, który odstępuje od dokonania z uwagi na okoliczność, że przedmiot czynności wykonawczej nie posiada wyobrażonej przez niego cechy, wcale nie oznacza, iż jego odstąpienie ma charakter dobrowolny, a tym samym wiąże się z koniecznością zastosowania art. $15 \S 1$ k.k. przewidującego klauzulę niepodlegania karze. SN słusznie wskazuje bowiem, iż „, [...] istotą dobrowolności odstąpienia od dokonania jest porzucenie przez sprawcę zamiaru popełnienia czynu zabronionego z własnej woli. Jeśli odnieść tę interpretację do motywacji sprawcy, który rezygnuje z dokonania wyłącznie dlatego, że obiekt nie spełnia jednak jego oczekiwań, to nie wydaje się, iż trafne byłoby uznanie, że sprawca porzucił dobrowolnie zamiar przestępczy" - uchw. SN z dnia 19 stycznia 2017 r., I KZP 16/16. OSNKW 2017/3/12.

59 A. Jezusek wskazuje, że nie każdy błąd co do przedmiotu czynności wykonawczej musi wykazywać się prawną relewantnością, a tym samym prowadzić do zakwalifikowania zachowania sprawcy jako przestępstwa usiłowania nieudolnego. Nawiązuje on przy tym do konstrukcji aberratio ictus (zboczenie działania) oraz error in personam/error in obiecto. Zdaniem przywołanego autora zboczenie działania polegające na spowodowaniu uszczerbku na innym obiekcie niż ten, na który skierowany był zamach sprawcy, ma charakter prawnie relewantny i powinno znaleźć odpowiednie odzwierciedlenie w kwalifikacji prawnej czynu. Natomiast wypadek błędu co do właściwości obiektu, na który sprawca skierował swój zamach (error in personam/error in obiecto), należy ocenić jako irrelewantny prawnie. W ocenie autora brak pożądanych przez sprawcę właściwości nie pozbawia obiektu, na który skierował on swój zamach, zdatności do popełnienia na nim czynu zabronionego, o ile stanowi desygnat znamienia przedmiotu czynności wykonawczej. A. JezuseK: Glosa do uchwaty SN..., s.163 i nast. 


\section{Podsumowanie}

Podejmując próbę syntetycznego podsumowania rozważań poczynionych w tekście, należałoby w pierwszej kolejności wskazać, iż usiłowanie stanowi jedną z najbardziej kontrowersyjnych instytucji prawa karnego. Wynika to zapewne $\mathrm{z}$ tego, że omawiana forma stadialna przestępstwa jest w dużej mierze skonstruowana z pojęć nieostrych, co stwarza dość rozległą przestrzeń do różnorodnego ich interpretowania. Należy przy tym zauważyć, że problemy koncentrujące się wokół wykładni poszczególnych znamion usiłowania dotyczą $\mathrm{w}$ istocie wyznaczania cezury pomiędzy przygotowaniem a usiłowaniem oraz między usiłowaniem udolnym a nieudolnym. Tym samym wiążą się one $\mathrm{z}$ wyznaczaniem granicy kryminalizacji, jak również zakresu odpowiedzialności karnej. Z tej perspektywy nie może dziwić okoliczność, że omawiana instytucja stanowi przedmiot niesłabnącego zainteresowania zarówno teoretyków, jak i praktyków prawa karnego.

Trzeba także wskazać, że różnice dotyczące rozumienia poszczególnych znamion składających się na instytucję usiłowania prowadzą do wyraźnych rozbieżności w orzecznictwie w zakresie kwalifikacji prawnej zbliżonych, a niekiedy nawet tożsamych stanów faktycznych. Taka praktyka orzecznicza jawi się jako sprzeczna z zasadą pewności prawa, która wymaga jednolitego traktowania jednostek znajdujących się w analogicznym położeniu. Ponadto prowadzi ona do sytuacji, w której adresat prawnokarnej normy nie jest w stanie ustalić, za jakie zachowania grozi mu odpowiedzialność karna bądź też w jakich granicach odpowiedzialność ta będzie się kształtować. Tym samym potrzeba wypracowania klarownych kryteriów interpretacji znamion konstytuujących tę formę stadialną przestępstwa wydaje się niezwykle aktualna.

Uściślając powyższe, należałoby wyjść od konstatacji, że usiłowanie udolne i nieudolne to dwa niezależne od siebie typy usiłowania o odmiennie ukształtowanych znamionach. Taki stan rzeczy wynika z zasadniczych różnic, jakie zachodzą między tymi dwiema figurami prawnymi, powodując jednocześnie, że karalność każdej z nich trzeba uzasadniać w autonomiczny sposób.

W dalszej kolejności warto zastanowić się, które zachowania posiadają cechę bezpośredniego zmierzania do dokonania, wyznaczając tym samym granicę między zawsze karalnym usiłowaniem a tylko wyjątkowo penalizowanym przygotowaniem. In abstracto nie da się oczywiście stworzyć zamkniętego katalogu form aktywności sprawcy, które in concreto odpowiadałyby definicji bezpośredniości. Jako słuszne jawi się jednak sformułowanie pewnych wskazówek interpretacyjnych, które pozwolą na zachowanie swoistej jednolitości pojęciowej bezpośredniego zmierzania. 
Analiza orzecznictwa prowadzi do wniosku, że najwłaściwszych kryteriów w tym względzie dostarcza koncepcja formalno-obiektywna. Z jednej strony nie zawęża ona znamienia bezpośredniości do rozpoczęcia „wykonywania” czynu zabronionego, z drugiej zaś w sposób nadmierny nie rozciagga sfery usiłowania, $w$ tym zwłaszcza na te zachowania sprawców, które będąc na tyle oddalone od dokonania, nie dają się powiązać $\mathrm{z}$ realizacją któregoś z rodzajowych typów przestępstwa za pomocą kryteriów obiektywnych.

Odnośnie do znamienia przedmiotu nadającego się do popełnienia na nim czynu zabronionego wydaje się, iż $\mathrm{w}$ procesie jego interpretacji nie należy zapominać o pewnych osobliwościach mających związek z usiłowaniem nieudolnym. Bezprawność omawianej instytucji determinowana jest bowiem przede wszystkim „złym zamiarem” sprawcy, bez którego nie jest możliwe przesądzenie naruszenia normy sankcjonowanej i sankcjonującej. Prawidłowe odczytanie zamiaru wymaga zaś przede wszystkim określenia, do czego sprawca zmierzał, a dokładniej - na jaki konkretnie „wycinek” rzeczywistości chciał oddziaływać. Przypisywanie odpowiedzialności w oderwaniu od tych ustaleń powoduje wyjście poza granice jego umyślności. Powyższe jest tym bardziej zasadne, jeśli weźmie się pod uwagę, że źródłem niebezpieczeństwa dla wartości chronionych prawem jest niebezpieczna wola jednostki, co oznacza, że skoncentrowanie zamiaru sprawcy na konkretnym obiekcie rzeczywistości nie powoduje automatycznego zagrożenia dla innych nośników dobra prawnego. Natomiast ewentualna modyfikacja zachowania sprawcy, tak, aby dokonanie czynu stało się możliwe, wiąże się z powstaniem nowego zamiaru, a w konsekwencji popełnieniem kolejnego przestępstwa. Wszystkie wymienione powyżej okoliczności wydają się zatem przemawiać za subiektywnym rozumieniem pojęcia przedmiotu nadającego się do popełnienia na nim czynu zabronionego.

Zaprezentowana wykładnia poszczególnych znamion usiłowania stanowi oczywiście pewną propozycję, która wydaje się jednak najbardziej przystawać do dogmatycznej oraz teoretycznej konstrukcji omawianej instytucji. W tym miejscu należy jedynie wskazać, że z uwagi na kształt elementów konstruujących figurę usiłowania jako wykluczone jawi się sformułowanie prostych „szablonów”, przy użyciu których zawsze, bez względu na konkretne okoliczności sprawy możliwe będzie przyporządkowanie rozpoznawanego stanu faktycznego do którejś normy prawnej dotyczącej form stadialnych przestępstwa. Wystarczające wydaje się jednak stworzenie określonych kierunków interpretacyjnych, które, nie pozbawiając organów orzekających pewnej swobody $\mathrm{w}$ procesie dokonywanej subsumcji, pozwolą na stopniowe ujednolicenie zapadających rozstrzygnięć. 


\section{Bibliografia}

\section{Literatura}

BuDZIŃsKi S.: Wykład porównawczy prawa karnego. Warszawa 1868.

GIEZEK J.: Formy popetnienia przestępstwa. W: Kodeks karny. Część ogólna. Komentarz. Red. IDEM. Warszawa 2007.

GIEZEK J.: Formy stadialne popetnienia przestępstwa $w$ polskim prawie karnym. „Annales Universitatis Mariae Curie-Skłodowska” 2013, vol. 60, nr 2.

GIEZEK J.: Glosa do uchwały Sądu Najwyższego z dnia 20 listopada 2000 r., sygn. I KZP 36/00. Prok. i Pr. 2001, nr 9.

GIEZEK J.: Świadomość sprawcy czynu zabronionego. Warszawa 2013.

GruszeCKA D.: Ochrona dobra prawnego na przedpolu jego naruszenia. Warszawa 2012.

JezUSEK A.: Glosa do uchwaty SN z dnia 19 stycznia 2017 r., I KZP 16/16. Prok. i Pr. 2017, nr 4.

JęDRZEJEWsKi Z.: Bezprawie usiłowania nieudolnego. Warszawa 2000.

Kма̨к K.: Glosa do uchwaty SN z dnia 19 stycznia 2017 r., I KZP 16/16. Prok. i Pr. 2017, nr 6.

KRAKOWIAK D.: Usiłowanie nieudolne z uwagi na brak przedmiotu a strona podmiotowa czynu usiłowanego. Glosa do uchwaty SN z dnia 19 stycznia 2017 r., I KZP 16/16. LEX/el. 2017.

LiszeWSKA A.: Formy stadialne popetnienia czynu zabronionego. W: System Prawa Karnego. Nauka o przestępstwie. Zasady Odpowiedzialności. T. III. Red. R. DębSKI. Warszawa 2017.

MAJEWSKI J.: O różnicy i granicy między usitowaniem udolnym a usiłowaniem nieudolnym. W: Formy stadialne i postacie zjawiskowe popetnienia przestępstwa. Red. IDEM. Torun 2007.

MAŁECKI M.: Glosa do uchwaty SN z dnia 19 stycznia 2017 r., sygn. I KZP 16/16. OSP 2017, nr 7-8.

Matecki M.: Przygotowanie do przestępstwa. Analiza dogmatycznoprawna. Warszawa 2016.

ReJMAN G.: Usitowanie przestępstwa w prawie polskim. Warszawa 1965.

SIEWIERSKI M.: Usiłowanie a przygotowanie wedtug kodeksu karnego. Pal. 1972, nr 5.

SitARz O.: Czynny żal zwiazany z usiłowaniem w polskim prawie karnym. Analiza dogmatyczna i kryminalnopolityczna. Katowice 2015.

WĄSEK A.: Glosa do uchwaty SN, sygn. I KZP 36/00. OSP 2001, nr 4.

Wróbel W: Formy stadialne $i$ postacie zjawiskowe popetnienia przestępstwa (Warszawa, 17 maja 2006 r.) - Zapis dyskusji. W: Formy stadialne i postacie zjawiskowe popetnienia przestępstwa. Materiaty III Bielańskiego Kolokwium Karnistycznego. Red. J. MajEwsKI. Torun 2007.

Zakrzewski P.: Przesłanka „bezpośredniości zmierzania” przy usiłowaniu nieudolnym a tzw. usiłowanie bezwzględnie nieudolne. CPKNP 2001, z. 4.

Zoll A.: Formy popetnienia przestępstwa. W: Kodeks Karny. Część Ogólna. Tom I. Komentarz do art. 1-52. Red. W. Wróbel, A. Zoll. Warszawa 2016. 


\section{Orzecznictwo}

Wyr. TK z dnia 17 lipca 2014 r., SK 35/12. OTK-A 2014/7/74.

Uchw. SN z dnia 20 listopada 2000 r., I KZP 36/00. OSNKW 2001/1-2/1.

Uchw. SN z dnia 19 stycznia 2017 r., I KZP 16/16. OSNKW 2017/3/12.

Post. SN z dnia 1 kwietnia 2005 r., IV KK 309/04. OSNKW 2005/9/79.

Post. SN z dnia 23 maja 2007 r., V KK 265/06. OSNKW 2007/7-8/58.

Post. SN z dnia 20 stycznia 2017 r., IV KK 438/16. LEX nr 2224613.

Wyr. SN z dnia 8 marca 2006 r., IV KK 415/05. LEX nr 183071.

Wyr. SN z dnia 27 lutego 2013 r., IV KK 288/12. LEX nr 1294452.

Wyr. SA w Łodzi z dnia 21 lutego 2002 r., II AKa 17/02. LEX nr 84233.

Wyr. SA w Katowicach z dnia 28 lutego 2002 r., II AKa 549/01. LEX nr 56778.

Wyr. SA we Wrocławiu z dnia 25 stycznia 2013 r., II AKa 400/12. LEX nr 1289607.

Wyr. SA we Wrocławiu z dnia 14 lutego 2013 r., II AKa 4/13. LEX nr 1289606.

Wyr. SA w Szczecinie z dnia 15 kwietnia 2013 r., II AKa 36/13. LEX nr 1313431.

Wyr. SA we Wrocławiu z dnia 24 kwietnia 2013 r., II AKa 108/13. LEX nr 1322854.

Wyr. SA w Lublinie z dnia 25 września 2013 r., II AKa 131/13. LEX nr 1381450.

Wyr. SA w Białymstoku z dnia 21 stycznia 2014 r., II AKa 259/13. LEX nr 1496372.

Wyr. SA w Szczecinie z dnia 22 maja 2014 r., II AKa 83/14. LEX nr 1506297.

Wyr. SA w Białymstoku z dnia 18 czerwca 2015 r., II AKa 73/15. LEX nr 1439168.

Wyr. SA w Szczecinie z dnia 3 marca 2016 r., II AKa 10/16. Legalis nr 1445853.

Wyr. SA w Lublinie z dnia 21 marca 2017 r., II AKa 17/17. LEX nr 2279554.

Wyr. SA w Katowicach z dnia 31 marca 2017 r., II AKa 48/17. LEX nr 2310584.

Wyr. SA w Katowicach z dnia 26 listopada 2018 r., II AKa 237/18. Biul.SAKa 2019/1/15.

Wyr. SA w Katowicach z dnia 25 kwietnia 2019 r., II AKa 415/17. LEX nr 2728176.

\section{Źródła internetowe}

Wyr. SO w Koszalinie z dnia 15 listopada 2103 r., V Ka 704/13. Źródło: http:// orzeczenia.ms.gov.pl/details/\$N/155510000002506_V_Ka_000704_2013_ Uz_2013-11-15_001 [dostęp: 22.03.2021].

Wyr. SO w Poznaniu z dnia 31 grudnia 2014 r., III K 250/14. Źródło: http:// orzeczenia.ms.gov.pl/details/\$N/153510000001506_III_K_000250_2014_ Uz_2015-01-22_001 [dostęp: 22.03.2021].

Wyr. SO w Krakowie z dnia 20 marca 2015 r., IV Ka 1058/14. Źródło: http:// orzeczenia.ms.gov.pl/details/\$N/152010000002006_IV_Ka_001058_2014_ Uz_2015-04-21_002 [dostęp: 22.03.2021].

Wyr. SO w Słupsku z dnia 5 października 2016 r., II K 37/16. Źródło: https:// www.saos.org.pl/judgments/251294 [dostęp: 22.03.2021].

Wyr. SO w Łodzi z dnia 17 października 2016 r., V Ka 547/16. Źródło: http:// orzeczenia.ms.gov.pl/details/\$N/152510000002506_V_Ka_000547_2016_ Uz_2016-10-17_001 [dostęp: 22.03.2021]. 
Wyr. SR dla Warszawy-Mokotowa w Warszawie z dnia 11 grudnia 2015 r., XIV K 220/15. Źródło: http://orzeczenia.ms.gov.pl/details/\$N/154505200007006_ XIV_K_000220_2015_Uz_2015-12-11_001 [dostęp: 22.03.2021]. 